\title{
Como terminar uma tese de sociologia: pequeno diálogo entre um aluno e seu professor (um tanto socrático)
}

\author{
Bruno Latour \\ Tradução: José Glebson Vieira, Leandro Mahalem de Lima e Uirá Felippe Garcia \\ Revisão técnica: Ana Cláudia Marques
}

(Um escritório na London School of Economics, em um fim de tarde de uma terça-feira escura de fevereiro, antes de sair para tomar uma cerveja em um pub. Batem à porta discreta, mas insistentemente. Um estudante entra no escritório)

Aluno: Estou atrapalhando?

Professor: De forma alguma. Este é o meu horário de plantão. Entre, sente-se.

A: Obrigado.

P: Então... Tenho a impressão de que está um pouco perdido?

A: Bem, sim. Tenho de lhe dizer que tenho dificuldades para aplicar a Teoria do Ator-Rede (Actor-Network Theory-ANT) em meu estudo de caso sobre as organizaçóes.

P: Não me surpreende. Ela não é aplicável a coisa alguma.

A: Mas nós aprendemos... quero dizer... ela parece ser bastante importante por aqui. Você está dizendo que ela é realmente inútil?

P: Ela pode ser útil, mas apenas se não for "aplicável” a qualquer coisa.

A: Desculpe-me, mas você não está tentando me pregar uma espécie de peça Zen, está? Devo alertá-lo, sou apenas um doutorando em estudo das organizaçóes, então não espere... Além disso, não estou muito a par da produção francesa; apenas li alguns dos Mil Platôs, mas não os entendi muito bem...

P: Desculpe-me. Eu não estava tentando fazer nenhuma gracinha. Apenas dizia que a ANT é, antes de tudo, um argumento negativo. Ela não diz nada de positivo sobre seja lá o que for.

A: Então, o que ela pode fazer por mim?

P: O melhor que ela pode fazer por você é algo do tipo: "Quando seus informantes misturam organização, hardware, psicologia e política em um mesmo enunciado, não reparta tudo isso por diferentes recipientes; tente, ao contrário, seguir as ligaçóes que eles fazem entre estes elementos, que pareceriam incomensuráveis se você seguisse as categorias acadêmicas usuais do social”. Isso é tudo. A ANT não pode lhe dizer positivamente o que é a ligação.

A: Então, por que ela é chamada de "teoria”, se ela não diz nada sobre as coisas que estudamos?

P: Ela é uma teoria, e penso que uma teoria forte, mas sobre como estudar as coisas, ou antes sobre como não estudá-las. Ou ainda, sobre como permitir que os atores tenham algum espaço para se expressarem.

A: Você quer dizer que as outras teorias sociais não permitem isso?

P: De uma certa maneira, sim. E isto, em razão mesmo do que constitui sua força: elas são muito boas em dizer coisas positivas acerca do que constitui o mundo social. $\mathrm{Na}$ maior parte dos casos é perfeito; os ingredientes são conhecidos, seu número pode se manter suficientemente limitado. Mas isto não funciona quando as coisas estáo se transformando rapidamente. E, eu acrescentaria, não, por exemplo, 
nos estudos organizacionais, ou nos estudos da informação, ou marketing, ou nos estudos de ciência e tecnologia, nos quais as fronteiras são terrivelmente fluidas. Novos campos: é aí que você vai precisar da ANT.

A: Mas meus agentes, atores, quero dizer, as pessoas que estudo na companhia, elas formam muitas redes. Elas estão conectadas a muitas coisas, elas estáo por toda parte...

P: Esse é, exatamente, o problema. Veja, você não precisa do Ator-Rede para dizer algo que qualquer teoria social disponível diria. É uma perda de tempo pegar este argumento táo bizarro para mostrar que seus informantes estão em uma rede.

A: Mas eles estão! Eles formam uma rede! Veja, eu tracei um esquema com as suas conexôes: chips de computador, padróes, educação, dinheiro, recompensas, países, culturas, diretorias corporativas, tudo. Não descrevi uma rede em sua concepção?

P: Não necessariamente. Eu concordo que isso tudo é terrivelmente confuso, e muito por nossa culpa - o termo que inventamos é bem horrível... Mas você não deve confundir a rede que é delineada pela descrição e a rede que é utilizada para fazer a descrição.

A: Como assim?

P: Certamente, você concordaria que desenhar com um lápis não é o mesmo que desenhar a forma de um lápis. É o mesmo com esta palavra ambígua: rede. Com o Ator-Rede você pode descrever algo que não se aparenta em nada com uma rede - um estado mental individual, uma parte de um maquinário, um caráter ficcional; inversamente, você pode descrever uma rede - metrôs, encanamentos, telefones - que não está delineada no modo como o Ator-Rede o faz. Você está, simplesmente, confundindo o objeto com o método. ANT é um método, e um método essencialmente negativo; ela não diz nada sobre a forma daquilo que ela permite descrever.
A: Isso é confuso! Mas os executivos de minha empresa não formam eles uma bela, reveladora e significativa rede?

P: Talvez, quero dizer, certamente sim - e daí?

A: Daí que eu posso estudá-la com a Teoria do Ator-Rede!

P: De novo talvez sim, talvez não. Isso depende inteiramente do que você permite que seus atores, ou melhor, seus actantes façam. Estar conectado, estar interconectado, ser heterogêneo, não é o suficiente. Tudo depende do tipo de ação que está fluindo de uma coisa para outra. Em inglês é mais claro: no termo network, há a net, a rede, e o work, o trabalho. $\mathrm{Na}$ verdade, deveríamos dizer worknet ao invés de network. É certamente o trabalho, o movimento, o fluxo e as mudanças que devem ser enfatizados. Mas agora estamos atados à network e todos pensam que nós nos referimos à World Wide Web ${ }^{1}$ ou algo do tipo.

A: Você quer dizer que mesmo eu tendo demonstrado que meus atores estão relacionados nos moldes de uma rede, ainda assim não realizei um estudo conforme a ANT?

P: É exatamente isso que quero dizer. A ANT é mais como o nome de um lápis ou um pincel do que o nome de um objeto a ser desenhado ou pintado.

A: Mas quando eu disse que a ANT era uma ferramenta e perguntei se ela poderia ser aplicada, você objetou!

P: Porque não é uma ferramenta - ou melhor, porque ferramentas nunca são "meras" ferramentas, prontas para serem aplicadas: elas sempre modificam os objetivos que você tinha em mente. Isto é o que "ator" significa. O Ator-Rede (eu concordo que o nome é tolo) permite que você produza alguns efeitos que jamais seriam obtidos por nenhuma outra teoria social. Isso é tudo que posso garantir. Uma

1. WWW, em português, significa "Rede Mundial de Computadores" [N.T]. 
experiência bem comum: tente desenhar com um lápis de grafite ou com um pedaço de carvão, você vai sentir a diferença; cozinhar uma torta num forno a gás não é o mesmo que num forno elétrico.

A: Mas não é isso que o meu orientador quer. Ele quer a moldura ${ }^{2}$ para um quadro na qual eu possa colocar meus dados.

P: Se você quer armazenar mais dados, compre um disco-rígido maior...

A: Ele sempre diz: "Você precisa de uma moldura”.

P: Ah? Então seu orientador negocia com pinturas? É verdade que molduras são interessantes: douradas, brancas, esculpidas, barrocas, em alumínio, etc. Mas você já conheceu algum pintor que iniciou sua obra-prima escolhendo primeiramente sua moldura? Seria um tanto estranho, não?

A: Você está fazendo jogo de palavras. Por "moldura", quero dizer uma teoria, um argumento, uma perspectiva geral, um conceito - algo que dê sentido aos dados. Sempre precisamos de uma.

P: Não, não precisamos! Diga-me: se algum $\mathrm{X}$ é um mero "caso de" $\mathrm{Y}$, o que é mais importante de ser estudado: $\mathrm{X}$, que é o caso específico, ou Y, que é a regra?

A: Provavelmente Y... mas também X, apenas para saber se realmente é uma aplicação de Y... Bem, acho que os dois.

$\mathrm{P}$ : Eu apostaria em $\mathrm{Y}$, uma vez que $\mathrm{X}$ não te ensinaria nada de novo. Se alguma coisa não é nada além de um "exemplo" de uma lei geral, estude, então, diretamente esta lei geral... Um estudo de caso que carece de ser complementado por uma moldura é um estudo de caso, já de saída, mal escolhido!

2. Optamos por traduzir os termos frame e framework como "moldura", tal como fizeram os tradutores da versão francesa, cadre. Em alguns casos optamos por traduzir framework como "quadro explicativo" [N.T].
A: Mas é preciso sempre colocar as coisas em seu contexto, não?

$P:$ Eu nunca entendi o que significaria esse contexto. A moldura torna um quadro mais bonito, ela pode ajudar a melhor dirigir o olhar, aumentar seu valor, mas ela não acrescenta nada à pintura. A moldura, ou o contexto, é precisamente o conjunto de fatores que náo alteram em nada os dados, aquilo que é de conhecimento comum sobre eles. Se eu fosse você, eu me absteria de toda e qualquer moldura. Descreva, simplesmente, o estado dos fatos que estão à mão.

A: "Descreva, simplesmente"! Desculpe-me, mas isso não é terrivelmente ingênuo? Não seria isto exatamente o mesmo tipo de empirismo, ou realismo, contra os quais fomos alertados? $\mathrm{Eu}$ achava que seu argumento fosse - como posso dizer? - mais sofisticado do que isso.

P: Porque você pensa que descrever é fácil? Você deve estar confundindo descrição com encadeamento de clichês. Para cada centena de livros de comentários, argumentaçóes, de glosas, há somente uma obra de descrição. Descrever, estar atento aos estados concretos das coisas, encontrar a narrativa adequada e única para uma situação dada - Eu pessoalmente sempre achei isso incrivelmente exigente. Já ouviu falar de Harold Garfinkel?

A: Devo dizer que estou perdido. Nos explicaram que há dois tipos de sociologia, a interpretativa e a objetivista. Certamente você não quer dizer que você é defensor do tipo objetivista?

P: Pode apostar que sim! Em todos os sentidos.

A: Você? Mas nos disseram que você era uma sorte de relativista! Você foi citado por dizer que mesmo as ciências naturais não são objetivas... Então, tudo indica que você é favorável a uma sociologia interpretativa, à multiplicidade de pontos de vista e de perspectivas, e tudo mais. 
P: Eu não tenho muita paciência com as sociologias interpretativas, seja lá o que você quiser chamar por este nome. Não. Ao contrário, acredito firmemente que as ciências são objetivas - o que mais elas poderiam ser? Elas tratam de objetos, não? Eu simplesmente digo que os objetos podem parecer um pouco mais complicados, entrelaçados, múltiplos, complexos, emaranhados, do que aquilo que o "objetivista”, como você diz, gostaria que eles fossem.

A: Mas é exatamente isso que as sociologias “interpretativas" argumentam, não?

$\mathrm{P}$ : Ah não, não mesmo. Elas diriam que os desejos humanos, os significados humanos, as intençôes humanas, etc., introduzem alguma "flexibilidade interpretativa” em um mundo de objetos inflexíveis, de "relaçóes puramente causais", de "conexôes estritamente materiais". Isto não é o que estou dizendo. O que diria é que este computador aqui em cima da mesa, esta tela, este teclado, enquanto objetos, esta escola são feitos de muitas camadas, exatamente do mesmo modo que você, sentado aqui, o é: seu corpo, sua linguagem, suas questões. É o objeto em si mesmo que acrescenta a multiplicidade, ou melhor, a coisa, a "reuniāo"3. Quando você fala em hermenêutica, não importa qual precaução tome, você sempre espera o segundo sapato cair: inevitavelmente, alguém acrescentará, "mas é claro que existe algo "natural", coisas "objetivas" que não são interpretadas".

A: É exatamente isso que ia dizer! Não há apenas realidades objetivas, mas também realidades subjetivas! É por isso que precisamos de ambos os tipos de teoria social...

P: Viu? Esta é a armadilha inevitável: "Não somente, mas também". Ou se estende o argumento a tudo, mas daí ele se torna inútil - "interpretação" se torna um outro sinônimo de "objetividade" - ou se limita o argumento a um aspecto da realidade, o humano, e, então você está atado - uma vez que a objetividade

3. Tradução de "assemblage" por "reuniāo". está sempre do outro lado da cerca. E náo faz diferença se consideram o outro lado mais verde ou mais podre; de qualquer modo, ele está sempre fora do alcance.

A: Mas você não negaria que você também possui um ponto de vista, que a ANT também é situada, que você também acrescenta uma outra camada de interpretaçóes, uma perspectiva?

P: Não, por que eu "negaria” isso? Mas e daí? A grande coisa sobre um ponto de vista é, precisamente, o fato de que você pode mudá-lo! Porque eu seria um prisioneiro dele? Da posição em que se situam na terra, os astrônomos têm uma perspectiva limitada, por exemplo em Greenwich, no Observatório situado rio abaixo desde daqui - você já foi lá? É fabuloso. E mesmo assim, eles têm conseguido trocar de perspectiva muito bem, através de instrumentos, telescópios, satélites. Eles agora já podem desenhar o mapa da distribuição das galáxias em todo o universo. Nada mal, não? Mostreme um ponto de vista, e eu lhe mostrarei duas dúzias de modos de alterá-lo. Ouça: toda esta oposição entre "ponto de vista" e "visão de parte alguma", você pode seguramente esquecer. E também esta diferença entre "interpretativo" e "objetivista”. Deixe a hermenêutica de lado e volte para seu objeto - ou melhor, para a coisa.

A: Mas, eu sempre estou limitado ao meu ponto de vista situado, à minha perspectiva, à minha própria subjetividade?

P: Você é bem obstinado! O que o faz achar que "ter um ponto de vista" significa "ser limitado", ou especialmente ser "subjetivo"? Quando você viaja e segue as placas "Belvedere", "Panorama", "Bella Vista", quando você finalmente chega àquele lugar que lhe tira o fôlego, de que maneira esta é uma prova de seus "limites subjetivos"? É a coisa em si mesma, o vale, os picos, as estradas que lhe oferecem este alcance, este toque, esta tomada. A melhor prova é que dois metros abaixo, você não pode ver nada por causa das árvores, e dois metros acima, também nada 
por causa de um estacionamento. E mesmo assim você tem a mesma limitação "subjetiva", e tem exatamente o seu mesmo "ponto de vista"! Se você pode ter diferentes pontos de vista sobre uma estátua, é porque a estátua em si mesma é tridimensional e lhe permite, sim, ela permite que você ande em torno dela. Se algo comporta uma multiplicidade de pontos de vista, é porque este algo é muito complexo, dotado de dobras intrincadas, bem organizado, e bonito, sim, objetivamente bonito.

A: Mas, certamente, nada é objetivamente bonito - beleza tem a ver com subjetividade... gosto e cor são relativos... Eu estou perdido de novo. Por que nós passaríamos tanto tempo combatendo o objetivismo, então? O que você diz náo pode estar certo.

P: Porque as coisas que as pessoas chamam de "objetivo" são, na maior parte dos casos, uma série de clichês. Nós não temos muitas boas descriçóes de nada: do que é um computador, um elemento de software, um sistema formal, um teorema, uma empresa, um mercado. Nós náo sabemos quase nada sobre o que é esta coisa que está estudando: organização. Como, entâo, poderíamos ser capazes de distinguíla da subjetividade? Então, há duas maneiras de criticar a objetividade: uma é se afastar do objeto para adotar o ponto de vista humano subjetivo. Mas é da outra direção que eu estou falando: a do retorno ao objeto. Porque deveríamos deixar os objetos serem descritos apenas pelos idiotas?! Os positivistas não são donos da objetividade. Um computador descrito por Alan Turing é um muito mais rico e mais interessante que aqueles descritos pela Wired $M a-$ gazine, não? Como vimos em sala ontem, uma usina de sabáo descrita por Richard Powers em Gain é bem mais viva do que aquela que você leu nos Harvard Case Studies. O nome do jogo é voltar ao empirismo.

A: Ainda assim, eu estou limitado à minha própria visão.
P: É claro que está, mas de novo, e daí? Não acredite em toda aquela bobagem de ser "limitado" a uma perspectiva. Todas as ciências têm inventado formas de se moverem de uma afirmação para outra, de um quadro de referência para outro, pelo amor de Deus: isso se chama relatividade.

A: Ah! Então você confessa ser um relativista!

P: Mas é claro, o que mais eu poderia ser? Se quero ser um cientista e alcançar objetividade, tenho de ser capaz de me mover de um quadro de referência para outro, de um ponto de vista para outro. Sem estes deslocamentos, eu estaria limitado ao meu estreito ponto de vista de uma vez por todas.

A: Então você associa objetividade e relativismo?

P: "Relatividade", sim, claro. Todas as ciências fazem o mesmo. Nossas ciências também.

A: Mas qual é a nossa maneira de mudar nossos pontos de vista?

P: Já lhe disse, as descrições são o nosso negócio. Todos os demais estão traficando clichês. Entrevistas, sondagens, o que seja - nós vamos, nós ouvimos, nós aprendemos, nós praticamos, nós nos tornamos competentes, nós mudamos nossa visão. De fato é bem simples: é chamado de trabalho de campo. Bons trabalhos de campo sempre produzem muitas novas descriçôes...

A: Mas eu já tenho muitas descrições. Estou afogado nelas. É exatamente este o meu problema. É por isso que estou perdido; é por isso que achei que seria útil vir até você. A Teoria do Ator-Rede náo pode me ajudar com esta massa de dados? Eu preciso de um quadro explicativo!

P: "Meu reino por um quadro!" Bem comovente, acho que entendo seu desespero. Mas não, a ANT é mesmo inútil para isso. Seu principal argumento é que os próprios atores fazem tudo, inclusive seus próprios quadros, suas próprias teorias, seus próprios contextos, 
sua própria metafísica, até mesmo sua própria ontologia... Então, temo que a direção a seguir seja: mais descriçóes.

A: Mas as descrições são longas demais. Ao invés disso, eu tenho que explicar.

P: Viu? É neste ponto que eu discordo da maior parte do treinamento em ciências sociais.

A: Você discordaria da necessidade das ciências sociais fornecerem uma explicação para os dados que elas acumularam? E você ainda se intitula um cientista social e um objetivista!

P: Eu diria que se sua descrição precisa de uma explicação, ela não é uma boa descrição, só isso. Apenas descriçóes ruins precisam de explicação. É bem simples, na verdade. O que se entende por "explicação", na maior parte das vezes? A adiçáo de um outro ator para prover àqueles já descritos a energia necessária para agir. Mas, se você tem que adicionar um ator, então a rede não está completa, e, se os atores já reunidos não têm energia suficiente para agir, então eles não são "atores", e sim meros intermediários, tolos ou marionetes. Eles não fazem nada, então não deveriam estar na descrição. Eu nunca vi uma boa descrição que precisasse de uma explicação. Mas, eu vi um sem número de descriçóes ruins para as quais nada foi acrescentado por uma adição massiva de "explicações"! E a ANT não ajudou...

A: Isso é bastante perturbador. Eu deveria saber - os outros estudantes me alertaram a não mexer com estas histórias de ANT nem mesmo com uma vara comprida... Agora você esta me dizendo que eu nem deveria tentar explicar qualquer coisa que seja!

P: Caro estudante, eu não disse isso, mas, simplesmente que ou a sua descrição é relevante e, na prática, você está adicionando um novo agente à descrição - a rede é simplesmente mais longa do que você pensava - ou, então, não é um ator que fará diferença e, neste caso, você está simplesmente adicionando algo irrelevante que não nos ajuda nem na descrição nem na explicação. Neste caso, jogue-a fora.

A: Mas todos os meus colegas se utilizam de um monte de explicaçóes: "a cultura corporativa da IBM", por exemplo, ou "o isolacionismo britânico", ou "a pressão do mercado", ou "o interesse individual". Por que eu deveria me privar de todas estas explicaçóes contextuais?

P: Você pode mantê-las, se isso lhe faz bem, mas não creio que elas expliquem coisa alguma - elas são meros ornamentos. No melhor das hipóteses elas são aplicáveis a todos os atores, o que significa que são absolutamente supérfluas, uma vez que são incapazes de introduzir uma diferença entre eles. $\mathrm{Na}$ pior, elas afogam todos os atores interessantes em um dilúvio de atores desinteressantes. Em regra geral, o contexto cheira mal. É apenas uma maneira de parar a descrição quando se está cansado ou com preguiça demais para continuar.

A: Mas é exatamente esse o meu problema: parar. Eu preciso terminar esta tese. Eu tenho apenas mais oito meses. E você sempre diz: "mais descriçóes". Mas isso é como Freud e suas curas: uma análise interminável. Quando devemos parar? Meus atores estão por toda parte! Para onde eu devo ir? O que é uma descrição completa?

P: Eis agora uma boa questão, pois é de questão prática. Como eu sempre digo: "uma boa tese é uma tese feita". Mas existe uma outra maneira de terminar uma tese que não "acrescentando uma explicaçáo" ou "colocando-a em um quadro explicativo".

A: Diga-me, então.

P: Você pára quando tiver escrito as suas 50.000 palavras ou, qualquer que seja o formato aqui na LSE, eu sempre me esqueço.

A: Oh! Isso é ótimo! Então, minha tese termina quando ela estiver completa... Isso ajuda muito, muito obrigado mesmo! Eu me sinto bem aliviado agora... 
P: Fico contente com sua satisfação. Não, falando sério, você não concorda que todo método depende do tamanho e do tipo de texto que você prometeu entregar?

A: Mas isso é um limite textual, não tem nada haver ver com o método.

P: Viu? De novo é por isso que discordo totalmente da maneira pela qual os doutorandos são treinados. Escrever textos tem tudo a ver com o método. Você escreve um texto de tantas palavras, em tantos meses, por uma certa quantia de dinheiro, baseado em tantas entrevistas, umas tantas horas de observação e tantos documentos. Isso é tudo. Não há mais nada a se fazer.

A: Mas é claro que há: eu aprendo, eu estudo, eu explico, eu critico, eu...

P: Mas todos esses objetivos grandiosos, você os alcança através de um texto, não?

A: Certamente, mas ele é uma ferramenta, um meio, uma maneira de me expressar.

P: Não há ferramentas, nem meios, apenas mediadores. Um texto é denso. Esse é um princípio da ANT, se ela tiver alguma.

A: Desculpe-me professor, como eu já lhe disse, eu nunca fiz maiores investimentos na produção filosófica francesa. Eu poderia compor linhas de programa em $\mathrm{C}$ ou em $\mathrm{C}++{ }^{4}$, mas eu náo domino Derrida, semiótica, ou algo do tipo. Eu não acredito que o mundo seja feito de palavras e coisas do gênero...

P: Não tente ser sarcástico. Isso não combina com o engenheiro que existe em você. $E$, de qualquer maneira, eu náo acredito nisto também. Você me perguntou como se faz para parar, eu só estou lhe dizendo que o máximo que você pode conseguir, como aluno de doutorado, é acrescentar, a um certo estado de conhecimento atual, um texto que possa ser lido pela banca examinadora, talvez por um punhado de informantes e dois ou três colegas de doutorado. Nada de muito extravagante nisso. Apenas

4. C e C++ são linguagens de programação de sistemas para computador [N.T]. um realismo raso. Uma solução é adicionar à sua análise um "modelo teórico", uma "explicação". A outra é escrever a última palavra do último capítulo dessa sua maldita tese.

A: Eu tenho uma formação científica! Eu sou engenheiro de sistemas - eu não vim para os Estudos de Organização para abandonar tudo isso. Eu pretendo adicionar defluxogramas, instituiçóes, pessoas, mitologias, psicologia a tudo que eu já conheço. Inclusive, eu estou preparado para ser "simétrico", tal como você nos ensinou, a respeito de todos aqueles fatores. Mas não me diga que ciência corresponde a contar belas histórias. Essa é a dificuldade com você. Em um momento você é completamente objetivista, e mesmo de um realismo ingênuo - "apenas descreva” - e em outro você é completamente relativista - "conte belas histórias e suma”. Isso é terrivelmente francês, não?

P: E isso faz de você terrivelmente o quê? Não seja tolo. Quem falou em "belas histórias"? Eu não, eu disse que você está escrevendo uma tese de doutorado. Pode negar isso? E depois eu disse que essa tese de tantas palavras - que será o único resultado duradouro de sua estada entre nós - deve ser densa.

A: $\mathrm{O}$ que isto quer dizer?

P: Isto quer dizer que ela não é uma vidraça transparente, que transporta as informaçóes sobre seu estudo sem deformá-las. "Não há informação, apenas trans-formação", tradução se preferir. Suponho que você esteja de acordo com este slogan da ANT? Bem, então ela deve ser verdadeira também para sua tese, não?

A: Talvez, mas, em que sentido isso pode me ajudar a ser mais científico, isso é tudo o que eu quero saber? Eu não quero abandonar o ethos da ciência.

P: Uma vez que o texto, segundo a maneira como é escrito, capture ou não a rede de atores que você quer estudar. $\mathrm{Na}$ nossa disciplina, o texto não é uma história, nem uma bela história, mas o equivalente funcional do laboratório. 
É o local dos testes, experimentos e simulaçôes. Dependendo do que se passa nele, há ou não há um ator, há ou não há uma rede sendo traçada. E isso depende inteiramente da maneira precisa como ele é escrito - e cada novo tópico exige uma nova maneira de ser tratado por um texto. A maior parte dos textos são fatalmente chapados. Nada acontece neles.

A: Mas ninguém fala sobre "texto" em nosso programa. Nós falamos sobre "estudar organizaçôes", não em "escrever" sobre elas.

P: É isso que estou falando a você: você está sendo mal treinado! Não ensinar aos alunos de doutorado em ciências sociais a escreverem suas teses é como não ensinar aos químicos fazerem experimentos laboratoriais. É por isso que atualmente eu só ensino a escrever. É verdade, eu me sinto como um velho cretino sempre repetindo a mesma coisa: "descreva, escreva, descreva, escreva..."

A: O problema é que não é isso que meu orientador quer. Ele quer que meu estudo de caso seja generalizável. Ele não quer uma "mera descriçáa”. Entáo, mesmo se eu fizer o que você quer, eu terei uma boa descrição de um determinado estado de coisas, e então? Então, eu ainda tenho que dispor tudo em um quadro explicativo, encontrar uma tipologia, comparar, explicar, generalizar. É por isso que começo a entrar em pânico.

P: Você só deve entrar em pânico se seus atores não tiverem feito tudo isso da mesma forma, constantemente, ativamente, reflexivamente, obsessivamente: eles também comparam, eles também produzem tipologias, eles também elaboram padróes, eles também disseminam suas máquinas, bem como suas organizaçóes, ideologias e estados mentais. Por que você seria aquele que faz o trabalho inteligente enquanto eles agiriam como um bando de retardados? $\mathrm{O}$ que eles fazem para expandir, para relacionar, para comparar e para organizar é também o que você tem a descrever. Não há outra camada a ser adicionada à "mera descrição". Náo tente trocar a descrição pela explicação: simplesmente continue com a descriçáo. As suas próprias idéias sobre a companhia não interessam se comparadas à questáo de como essa parte da empresa tem feito para se desenvolver.

$S:$ Mas, se as pessoas não atuam, se elas não comparam ativamente, padronizam, organizam, generalizam, o que eu faço? Eu estarei perdido! Eu serei incapaz de produzir outras explicaçóes.

P: Você é mesmo extraordinário! Se seus atores não atuam, eles não deixarão qualquer rastro que seja. Assim, você não terá nenhuma informação. Então você não terá nada a dizer.

S: Você quer dizer que, quando não há nenhum rastro, devo permanecer em silêncio?

P: Incrível! Você poderia levantar essa questão em qualquer uma das ciências naturais? Ela soaria completamente tola. Só um cientista social para achar que pode continuar com a explicação mesmo na ausência de informação! Você está realmente preparado para produzir dados?

A: É claro que não, mas eu ainda quero...

P: Bom, pelo menos você é mais razoável que muitos dos seus colegas. Se não há rastro, conseqüentemente não há informação, não há descrição, e por isso não há conversa. Não preencha com nada. É como um mapa de um país no século XVI: ninguém foi até lá, ou ninguém de lá voltou, por isso, pelo amor de Deus, deixe-o em branco! Terra incógnita.

$S$ : Mas, e as entidades invisíveis que atuam escondidas por aí?

P: Se elas atuam, elas deixam rastro, desse modo você tem alguma informação, e desse modo pode falar sobre elas. Caso contrário, cale a boca.

A: Mas e se elas estão reprimidas, rejeitadas, silenciadas?

P: Não há nada no mundo que permita dizer que elas estão lá sem que se apresente provas de sua presença. Essa prova pode ser indireta, 
exigente, complicada, mas você precisa dela. Coisas invisíveis são invisíveis. Ponto. Se elas fazem com que outras coisas se movam, e você pode documentar esses movimentos, então elas são visíveis. De novo, ponto

S: "Prova, prova". O que afinal é uma prova"? Isto não é terrivelmente positivista?

P: Espero que sim. O que há de tão incrível em dizer que as coisas, cuja a existência você não pode provar, atuam? Eu temo que você esteja confundindo teoria social com teoria da conspiração - embora, nos dias de hoje, eu concorde que isso ocorra na maior parte das teorias críticas em ciências sociais.

A: Mas se eu não adicionar nada, estarei simplesmente repetindo o que os atores dizem.

P: Qual seria a utilidade de acrescentar entidades invisíveis que atuam sem deixar nenhum rastro, e que não fazem diferença para um estado de coisas qualquer?

A: Mas eu devo ensinar aos atores algo que não saibam; caso contrário, por que eu os estudaria?

P: Vocês, cientistas sociais, sempre me desconcertam. Se você estudasse formigas (ants), ao invés de ANT, esperaria que elas aprendessem alguma coisa sobre seu estudo? Claro que não. Elas sabem, você não. Elas são professoras, você aprende com elas. Você explica o que elas fazem para você mesmo, para o seu próprio benefício ou para o dos outros entomólogos, não para elas, que não dão a mínima. $\mathrm{O}$ que o faz pensar que um estudo sempre supóe ensinar coisas às pessoas estudadas?

A: Mas esse é o projeto das ciências sociais! É por isso que estou aqui na LSE: para criticar a ideologia gerencial, desconstruir os muitos mitos da tecnologia da informação, para adquirir uma postura crítica sobre as inovaçóes técnicas e a ideologia de mercado. Se não for isso, acredite, eu ainda estaria no Vale do Silício, e estaria fazendo um monte de dinheiro - bem, pode ser que eu náo estivesse agora, já que a bolha da internet estourou ${ }^{5}$... Mas, de qualquer forma, eu tenho que fornecer às pessoas algum entendimento reflexivo...

P: ... que antes de você chegar, claro, não eram reflexivas!

A: De certa maneira, sim. Não? Eles faziam coisas, mas sem saber por que... O que há de errado nisto?

P: O que há de errado é que isso é terrivelmente mesquinho. Muito do que os cientistas sociais chamam de "reflexividade" se resume em perguntar às pessoas coisas totalmente irrelevantes; estas, por sua vez, fazem outras perguntas para as quais o analista náo possui o mais ínfimo começo de resposta. A Reflexividade não é um direito inato, algo que pode levar com você apenas porque está na LSE! Você e seus informantes têm diferentes interesses - quando eles se intersectam é um milagre, e milagres, caso você não saiba, são raros...

A: Mas, se eu não adicionar nada a que os atores dizem, eu serei incapaz de ser crítico.

P: Está vendo, em um momento você quer explicar e bancar o cientista, enquanto em outro quer desconstruir, criticar e bancar o militante...

A: E eu diria: em um momento você é um relativista ingênuo - de volta ao objeto - e no momento seguinte você diz que apenas escreve um texto no qual náo adiciona nada, mas apenas segue seus famosos "atores". Isso é totalmente apolítico. Nenhuma postura crítica que eu possa enxergar.

P: Diga-me, Mestre Desconstrutor, como você vai obter um "paradigma crítico" às custas de seus atores? Estou ansioso para ouvir.

A: Apenas se eu tiver um quadro explicativo. Era isso que estava procurando quando vim

5. O autor refere-se ao esgotamento da chamada "dotcom bubble", o conjunto de empresas ponto-com que apareceram entre 1995-2005 no Vale do Silício e boa parte delas entraram em faleência devido ao estouro dessa "bolha" [N.T] 
aqui, mas obviamente a ANT é incapaz de me fornecer um.

P: Fico muito contente por ela náo lhe oferecer. Esse seu quadro, o qual eu assumo que está oculto aos olhos dos seus informantes, é revelado pelo seu estudo?

A: Sim, com certeza. Pelo menos eu espero que este seja o valor de meu trabalho. Não a descrição, uma vez que todos a conhecem de alguma maneira; mas a explicação, o contexto que eles não têm tempo para ver, a tipologia... Veja, eles estáo muito ocupados para pensar. Isso é tudo que posso proporcionar; e, a propósito, na companhia eles estão interessados, prontos para me ofereceram acesso aos seus arquivos, e com intenção de pagar por isso!

P: Bom para você... O que você está me dizendo é que nos seus seis meses de trabalho de campo, você pode, por si próprio, apenas por ter escrito algumas centenas de páginas, produzir mais conhecimento do que aqueles 340 engenheiros e a diretoria que você tem estudado?

A: Não "mais" conhecimento, talvez, mas sim um conhecimento diferente, eu espero. Eu não deveria me esforçar exatamente para isto? Não é por isso que estou neste negócio?

$\mathrm{P}$ : Eu não estou certo do negócio em que você está, mas em quão diferente é o conhecimento que você produz em relaçáo ao deles, esta é toda a questão.

A: É o mesmo tipo de conhecimento de todas as ciências, o mesmo modo de explicar as coisas: indo do caso específico até a causa, e uma vez que eu conheço a causa, eu posso gerar seu efeito como conseqüência. $\mathrm{O}$ que há de errado nisso? É como perguntar o que acontece a um pêndulo que foi retirado de seu equilíbrio; se eu conheço a lei de Galileu, eu nem preciso mais olhar para qualquer pêndulo concreto; eu sei exatamente o que acontecerá, desde que, claro, eu esqueça as perturbaçóes.
P: Claro...! Entáo, o que você quer é que seu quadro explicativo seja para o seu estudo de caso o que a lei de Galileo é para a queda de um pêndulo - menos as perturbaçóes.

A: Sim, acho que sim, de certo modo, embora naturalmente menos preciso cientificamente. Por quê? O que há de errado com isso?

P: Nada, seria ótimo, mas isto é viável? Significa que, o que quer que um pêndulo concreto faça, isso não acrescentaria nenhuma informação nova à lei dos corpos em queda. As leis contêm in potentia tudo o que há para se conhecer sobre o estado de coisas de um pêndulo. O caso concreto é simplesmente, para falar como os filósofos, a "realização de um potencial" que já está lá.

A: Esta não é uma explicação ideal?

P: Este é justamente o problema: é um ideal elevado ao quadrado: é o ideal de uma explicação ideal. Eu duvido seriamente que os funcionários da companhia se comportem assim. E eu estou bem convencido de que você não pode produzir a lei do comportamento deles que permitiria que você deduzisse tudo como a realização in concreto daquilo que já estava lá potencialmente.

A: Menos as perturbaçóes...

P: Sim, sim, sim, desnecessário acrescentar... sua modéstia é admirável.

A: Você está brincando comigo? Entretanto, empenhar-se na busca deste tipo de quadro explicativo parece-me viável...

P: Mas, mesmo que o fosse, seria desejável? Veja, o que você está realmente me dizendo é que na sua descrição os atores não fazem qualquer diferença. Eles simplesmente realizaram um potencial - aparte os desvios menores. $\mathrm{O}$ que significa que eles não são, de fato, atores: eles simplesmente carregam uma força que passa através deles. Então, meu caro estudante, você tem desperdiçado seu tempo descrevendo pessoas, objetos, locais que não são nada, de fato, além de intermediários passivos, uma 
vez que eles náo fazem nada por si próprios. O tempo que você passou no campo foi um desperdício. Você deveria ter ido diretamente à causa.

A: Mas é para isso que serve a ciência! Justamente isso: encontrar a estrutura oculta que explica o comportamento daqueles agentes que você pensava estarem fazendo algo, mas que são simplesmente ocupantes do lugar ${ }^{6}$ de alguma outra coisa.

P: Então, você é um estruturalista! Finalmente você saiu do armário. Ocupantes de lugar, é isso o que você chama de atores?! E você quer, ao mesmo tempo, usar a Teoria do AtorRede! Isto é estender por demais os limites do ecletismo.

A: Por que não posso fazer ambos? Certamente, se a ANT tem algum conteúdo científico, ele tem que ser estruturalista.

P: Você notou que há a palavra "ator" em ator-rede? Você pode me dizer que tipo de ação os ocupantes de lugar fazem em uma explicação estruturalista?

A: É fácil, ele preenche uma função. Essa é a grande coisa sobre o estruturalismo, se eu o entendi corretamente. Qualquer outro agente na mesma posição seria obrigado fazer o mesmo...

P: Então, um ocupante de lugar é, por definição, inteiramente substituivel por qualquer outro?

A: Sim, é isto que estou dizendo.

P: O que é igualmente tolo e que o torna radicalmente incompatível com a ANT: um ator que não faz diferença, no meu vocabulário, não é um ator. Um ator, se as palavras têm algum significado, é exatamente o que não é substituível. É um evento único e totalmente irredutível a qualquer outro, exceto se você o torna comensurável com outro através de algum tipo de padronização - mas mesmo isso requer um terceiro ator, um terceiro evento.

6. Place holders, no original. [N.T]
A: Entáo, você está me dizendo que a ANT não é uma ciência?

P: Não uma ciência estruturalista, por certo.

A: O que dá no mesmo, toda ciência...

P: Não! Se informação é transformação, não importa qual o campo. Os estudos de organização, estudos de ciência e tecnologia, estudos de negócios, estudos de informação, sociologia, geografia, antropologia, por definição, não podem depender de uma explicação estruturalista.

A: "Sistemas de transformações", é disso exatamente que o estruturalismo se ocupa!

P: De maneira alguma, meu amigo, no estruturalismo nada é realmente transformado, é apenas combinado. Você não compreende a distância abissal entre ele e a ANT. Uma estrutura é justamente uma rede sobre a qual você tem apenas informação aproximativa. É útil quando você é pressionado pelo tempo, mas não me diga que isso é mais científico. Se eu quero ter atores em meu relato, eles têm que fazer algo, não serem apenas ocupantes de lugar; se eles fazem algo, eles marcam uma diferença. Se eles não fazem diferença, abandone-os e recomece a descrição. Você quer uma ciência na qual não exista objeto.

A: Você e suas histórias... Histórias memoráveis, é o que você quer! Eu estou falando sobre explicação, conhecimento, posturas críticas, náo escrevendo roteiro para novelas de TV do Canal 4!

P: Retomando o que já disse. Você quer que o seu calhamaço de algumas centenas de páginas faça a diferença, não?! Bom, então você tem que ser capaz de provar que sua descrição do que as pessoas fazem, de quando seu texto retornar a elas, faz diferença sobre o modo como estão fazendo as coisas. É isto que você chama como "postura crítica"?

A: Eu suponho que sim.

P: Mas, então, você concordaria que não serviria de nada lhes falar de causas que não trazem nenhuma diferença para o que eles fazem já que são excessivamente gerais? 
A: Claro que não. Eu estava falando de causalidades reais.

P: Mas estas tampouco lhes serviriam, porque mesmo que existissem, o que eu duvido muito, elas não teriam nenhum outro efeito além de transformar seus informantes em ocupantes do lugar de outros atores, o que você chamou de função, estrutura, etc. Assim, de fato, eles seriam não atores, mas, idiotas, marionetes - aliás, menos que marionetes já que elas forçam os titereiros a fazer coisas inesperadas...Bem, em todo o caso, você está fazendo com que os atores sejam nada: na melhor das hipóteses eles poderiam adicionar algumas perturbações menores, tal como o pêndulo concreto que adiciona somente pequenas oscilaçóes.

A: Âh?

P: Agora você tem de me dizer o que há de tão politicamente grandioso em transformar aqueles que você estudou em inofensivos e inativos ocupantes de lugar para as funçóes escondidas que você, e só você, consegue detectar.

A: Humm, você tem um modo de colocar tudo de cabeça para baixo... Não estou táo certo agora. Se os atores tomam consciência das determinaçóes impostas a eles... mais conscientes... mais reflexivos... seu grau de consciência não seria de algum modo elevado? Eles agora podem tomam seu destino em suas próprias mãos. Eles se tornam mais esclarecidos, não? E, se este é o caso, eu diria que agora, pelo menos, em parte graças a mim, eles são mais ativos agora, são atores mais completos.

P: Bravo, bravissimo! Então, para você, um ator é um agente plenamente determinado, mais um ocupante de lugar para uma função, mais um pouco de perturbação, mais alguma consciência provida a eles por um cientista social esclarecido? Horrível, simplesmente horrível... E você quer aplicar a ANT a estas pessoas? Depois de você tê-los reduzido de atores a ocupantes de lugar, você quer adicionar um insulto à injúria e, generosamente, trazer a estes pobres blocos a reflexividade que eles já tinham antes e que você retirou deles ao tratá-los de uma maneira estruturalista! Magnífico! Eles eram atores antes de você vir com a sua "explicação". Não me diga que é o seu estudo que os fará o serem. Ótimo trabalho, aluno. Bourdieu não o teria feito melhor...

A: Você pode não gostar muito de Bourdieu, mas pelo menos ele era um verdadeiro cientista, e melhor ainda, ele era politicamente relevante. Até onde posso dizer, a sua ANT não é nem uma coisa nem outra...

P: Obrigado. Há trinta anos eu estudo as conexôes entre a ciência e a política, de modo que é um tanto difícil me intimidar com conversas sobre qual ciência é "politicamente relevante".

A: Argumentos de autoridade também não me intimidam, de modo que não faz qualquer diferença para mim os seus trinta anos de estudo.

P: Touché... Mas a sua questão era: "O que eu posso fazer com a ANT?" Eu respondi: nenhuma explicação estruturalista. As duas são completamente incompatíveis. Ou você tem atores que realizam potencialidades e eles náo são atores de fato, ou você descreve atores que estáo atualizando virtualidades (esta é a maneira de Deleuze, a propósito), e isto demanda textos muito específicos. Sua conexáo com aqueles que você estuda demanda protocolos bem específicos de trabalho - eu acho que é isso que você chamaria de "postura crítica" ou "relevância política".

A: Então em quê somos diferentes? Você também quer ter uma postura crítica.

P: Sim, talvez, mas estou certo de uma coisa: não é automático, e na maior parte do tempo, ela vai falhar. Duzentas páginas de entrevistas, observaçóes, etc. não farão, de qualquer jeito, nenhuma diferença por si mesmas. Para serem relevantes, outro conjunto de circunstâncias extraordinárias é exigido. Trata-se de um evento raro. Exige um protocolo imaginativo incrível. 
Tão grande, tão raro, tão surpreendente quanto Galileu com seu pêndulo, ou Pasteur com seu vírus da raiva.

A: Então o que eu devo fazer? Rezar por um milagre? Sacrificar uma galinha?

P: Mas por que que você quer que seu pequeno texto seja automaticamente mais relevante para aqueles a quem ele se refere do que, digamos, para um laboratório gigante de ciências naturais? Olhe o quanto leva pra os chips da Intel $^{\mathrm{TM}}$ se tornarem relevantes para os telefones celulares! E você quer que todos tenham um rótulo "LSE ${ }^{\mathrm{TM}}$ inside" sem nenhum custo? Para se tornar relevante você precisa de trabalho extra.

A: Justamente o que eu precisava: a perspectiva de mais trabalho ainda!

P: Mas esse é o ponto: se um argumento é automático, pronto de antemão, em todos os propósitos, então este argumento não pode ser científico. É simplesmente irrelevante. Se um estudo é realmente científico, ele pode falhar.

A: Muito animador, foi muito gentil você me lembrar que minha tese pode falhar!

P: Você confunde ciência com posição de superioridade. Diga-me, você é capaz de imaginar um único tópico para o qual, por exemplo, a sociologia crítica de Bourdieu, da qual você gosta tanto, não seja aplicável?

A: Mas eu não posso imaginar um único tópico para o qual a ANT seja aplicável!!

P: Formidável, você tem razão, é exatamente isso o que eu penso...

A: Isso náo pretendia ser um elogio.

P: Mas eu o tomo como um verdadeiro elogio! Uma aplicação de alguma coisa é tão rara quanto um bom texto de ciências sociais.

A: Deixe-me respeitosamente lembrá-lo que, com toda sua excepcionalmente sutil filosofia da ciência, você ainda não me disse como escrever um.

P: Você estava tão ansioso em adicionar molduras, contextos, estruturas, à sua "mera descrição", como você poderia ter me escutado?
A: Mas qual a diferença entre um bom e um mau texto em ANT?

P: Agora sim, esta é uma boa questão!

A: Finalmente?

P: Finalmente! Resposta: a mesma que existe entre um bom e um mau laboratório. Nem mais, nem menos.

A: Bem, ok, hum, obrigado... Foi gentil de sua parte conversar comigo. Mas acho que depois de tudo, ao invés de ANT... Estava pensando em utilizar a teoria dos sistemas de Luhmann como um enquadramento subjacente - ela parece ser bem promissora, "autopoiesis" e tudo mais. $\mathrm{Ou}$ talvez eu vá usar um pouco de ambas.

P: Hum...

A: Você não gosta de Luhmann?

P: Eu deixaria de lado todos os "enquadramentos subjacentes", se eu fosse você.

A: Mas, o seu tipo de "ciência", pelo que pude notar, significa quebrar com todas as regras de nosso treinamento em ciências sociais.

P: Eu prefiro quebrá-las todas e seguir os meus atores... Como você disse, eu sou, no final, um realista ingênuo, um positivista.

A: Sabe o que seria realmente legal? Uma vez que ninguém por aqui parece entender o que a ANT é, você deveria escrever um guia sobre ela. Isso certamente faria nossos professores saberem o que ela é e entáo, se me permite dizer, eu não quero ser indelicado... mas talvez assim eles não tentariam nos empurrar tanto para ela... se você entende o que quero dizer...

P: Então, é tão mal assim? Hum, um guia?

A: Veja, eu sou apenas um estudante de $\mathrm{PhD}$. Você é um professor. Você já publicou muito, você pode arcar com coisas que eu não posso. Eu tenho que escutar meu orientador. Eu simplesmente náo posso levar seu conselho muito adiante.

P: Então, por que veio até mim? Por que tentou usar a ANT?

A: Na última meia-hora, devo confessar, estive me perguntando a mesma coisa... 


\section{Nota dos tradutores}

Traduzido do original: "A prologue in form of a dialog between a Student and his (somewhat) Socratic Professor". In Avgerou, C.; Ciborra, A.; Land. F.F. (orgs.). 2004. The Social Study of Information and Communication Study. Nova Iorque: Oxford Univ. Press, pp. 62-76.

Cotejado com as seguintes versôes: "On the Difficulty of being an ANT: An Interlude in Form of Dialog". In Latour, B. 2005. Reassem- bling the Social - an Introduction to Actor-Network Theory. Oxford: Oxford Univ. Press, pp. 141-156. E: "Comment finir une these de sociologie. Petit dialogue entre un étudiant et um professeur (quelque peu socratique). In Caillé, A.; Dufoix, S. (orgs.). 2004. Une théorie sociologique générale est-elle pensable?. La revue $d u$ M.A.U.S.S., n. 34, pp. 154-172.

A primeira versão em inglês e a versão francesa estão disponíveis em http://www.brunolatour.fr

\author{
tradutor José Glebson Vieira \\ Doutorando em Antropologia Social / USP \\ tradutor Leandro Mehalem de Lima \\ Mestrando em Antropologia Social / USP \\ tradutor Uirá Felippe Garcia \\ Doutorando em Antropologia Social / USP \\ revisor técnico Ana Cláudia Marques \\ Professora do Departamento de Antropologia / USP
}

Recebido em 20/01/2007

Aceito para publicação em 30/01/2007 